\section{Multiple punctate cerebral hemorrhages in acute leukemia with blast crisis}

Sherry H.-Y. Chou, MD; and Aneesh B. Singhal, MD, Boston, MA

A 56-year-old man and a 29-year-old woman presented to our hospital with symptoms of headache and encephalopathy. Both patients proved to have acute myeloid leukemia with marked leukocytosis, elevated blast counts, and thrombocytopenia. Brain MRI gradient-echo images showed an unusual miliary pattern of multiple acute, small cerebral hemorrhages involving the cerebral hemispheres and the corpus callosum. It is believed that marked leukocytosis results in hyperviscosity, leukostasis, hypoxic vasodilatation, and eventual rupture of small cerebral vessels. ${ }^{1,2}$ Both patients regained normal neurologic function after induction chemotherapy, suggesting that this pattern of hemorrhage is not necessarily associated with poor prognosis (figure).

1. Kawanami T, Kurita K, Yamakawa M, Omoto E, Kato T. Cerebrovascular disease in acute leukemia: a clinicopathological study of 14 patients. Intern Med 2002;41:1130-1134.

2. Nowacki P, Zdziarska B, Fryze C, Urasinski I. Co-existence of thrombocytopenia and hyperleukocytosis ("critical period") as a risk factor of haemorrhage into the central nervous system in patients with acute leukaemias. Haematologia (Budap) 2002;31:347-355.

Disclosure: The authors report no conflicts of interest.

Address correspondence and reprint requests to Dr. Aneesh B. Singhal, J. Philip Kistler Stroke Research Center, 175 Cambridge Street, Suite 300, Massachusetts General Hospital, Boston, MA 02114; e-mail: asinghal@partners.org
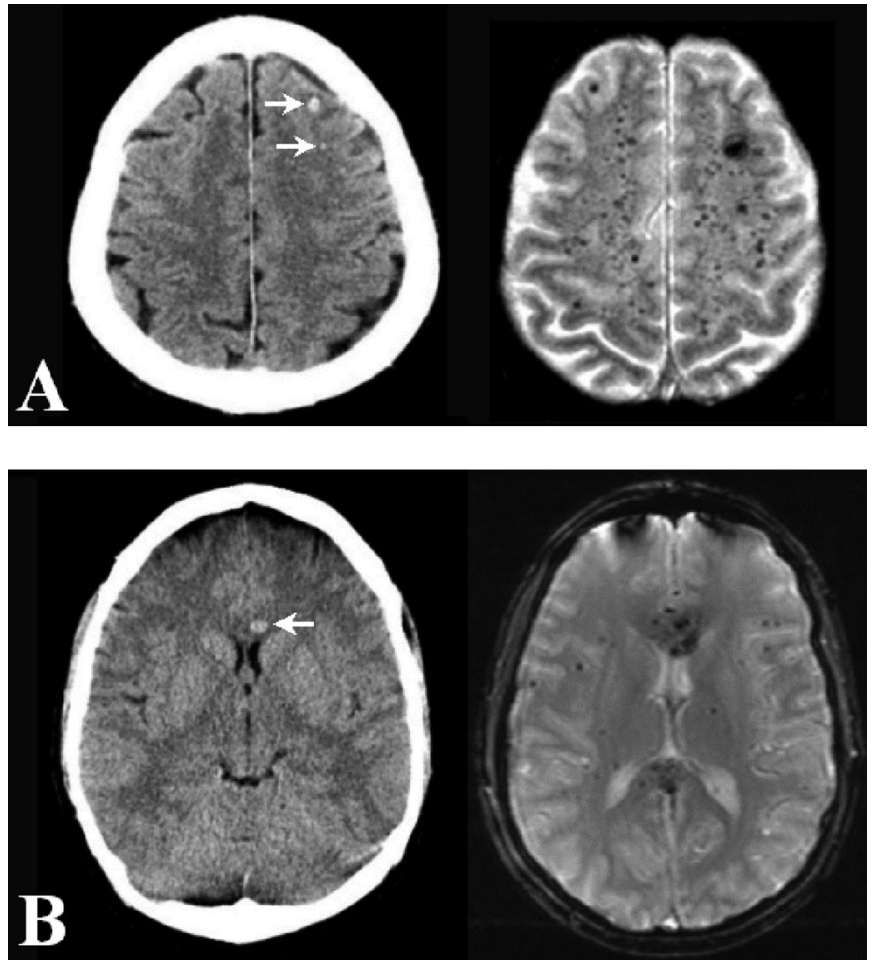

Figure. Patient 1 (A) and Patient 2 (B). Noncontrast head CT scan image (left panel) shows a few scattered cerebral hemorrhages (arrows). The corresponding gradient-echo MR image (right panel) shows an unusual miliary pattern of numerous punctate cerebral hemorrhages. 


\section{Neurology}

\section{Multiple punctate cerebral hemorrhages in acute leukemia with blast crisis \\ Sherry H.-Y. Chou and Aneesh B. Singhal \\ Neurology 2007;68;953 \\ DOI 10.1212/01.wnl.0000257151.61125.51}

This information is current as of March 19, 2007

\section{Updated Information \& Services}

References

Subspecialty Collections

Permissions \& Licensing

Reprints including high resolution figures, can be found at: http://n.neurology.org/content/68/12/953.full

This article cites 2 articles, 0 of which you can access for free at: http://n.neurology.org/content/68/12/953.full\#ref-list-1

This article, along with others on similar topics, appears in the following collection(s):

All Cerebrovascular disease/Stroke

http://n.neurology.org/cgi/collection/all_cerebrovascular_disease_strok $\mathrm{e}$

CT

http://n.neurology.org/cgi/collection/ct

Hematologic

http://n.neurology.org/cgi/collection/hematologic

Intracerebral hemorrhage

http://n.neurology.org/cgi/collection/intracerebral_hemorrhage

Information about reproducing this article in parts (figures,tables) or in its entirety can be found online at:

http://www.neurology.org/about/about_the_journal\#permissions

Information about ordering reprints can be found online:

http://n.neurology.org/subscribers/advertise

Neurology ${ }^{\circledR}$ is the official journal of the American Academy of Neurology. Published continuously since 1951, it is now a weekly with 48 issues per year. Copyright. All rights reserved. Print ISSN: 0028-3878. Online ISSN: 1526-632X.

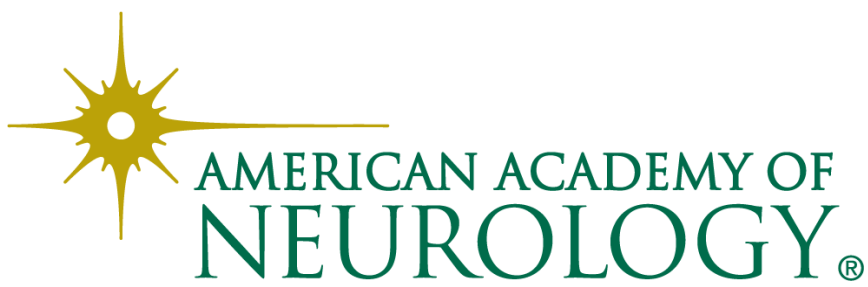

